No. 1

Review Article

1 Peroxisome Proliferator-Activated Receptor-Alpha and Atherosclerosis: From Basic Mechanisms to Clinical Implications

Israelian-Konaraki, Z.; Reaven, P.D. (Phoenix, Ariz.)

General Cardiology

10 Tissue pH Determination for the Detection of Metabolically Active, Inflamed Vulnerable Plaques Using Near-Infrared Spectroscopy: An in-vitro Feasibility Study

Khan, T.; Soller, B. (Worcester, Mass.); Naghavi, M.; Casscells, W. (Houston, Tex.)

17 Angiotensin-Converting Enzyme Inhibitor Use in Elderly Patients Hospitalized with Heart Failure and Left Ventricular Systolic Dysfunction

Rangaswamy, C. (Ann Arbor, Mich.); Finn, J.I. (Oak Brook, Ill.); Koelling, T.M. (Ann Arbor, Mich.)

24 Implementation of the ACC/AHA Guidelines for Preoperative Cardiac Risk Assessment in a General Medicine Preoperative Clinic: Improving Efficiency and Preserving Outcomes

Almanaseer, Y.; Mukherjee, D.; Kline-Rogers, E.M.; Kesterson, S.K.; Sonnad, S.S.; Rogers, B.; Smith, D.; Furney, S.; Ernst, R.; McCort, J.; Eagle, K.A. (Ann Arbor, Mich.)

Arrhythmia and Electrophysiology

30 Electrocardiographic Pattern as a Guide for Management and Radiofrequency Ablation of Idiopathic Ventricular Tachycardia Tanner, H.; Wolber, T.; Schwick, N.; Fuhrer, J.; Delacretaz, E. (Bern)

\section{Coronary Care}

37 Resumption and Maintenance of Employment after a First Acute Myocardial Infarction: Sociodemographic, Vocational and Medical Predictors

Drory, Y. (Tel Aviv); Kravetz, S. (Ramat Gan); Koren-Morag, N.; Goldbourt, U.; Israel Study Group on First Acute Myocardial Infarction (Tel Aviv)

44 The Outcome of Coronary Artery Bypass Grafting Surgery among Patients Hospitalized with Acute Coronary Syndrome: The Euro Heart Survey of Acute Coronary Syndrome Experience Solodky, A. (Petah Tikva); Behar, S.; Boyko, V. (Tel Hashomer); Battler, A.; Hasdai, D. (Petah Tikva)
Noninvasive and Diagnostic Cardiology

48 Predictors of Cardiovascular Death in Patients with a Left Ventricular Restrictive Filling Pattern of the Mitral Inflow Boccalandro, F. (Odessa, Tex./Houston, Tex.); Loghin, C.; Seung-Ho, K. (Houston, Tex.); Barasch, E. (Roslyn, N.Y.)

Letters to the Editor

53 Sudden Death due to Cardiac Tamponade Caused by Metastasis of Squamous Cell Carcinoma of the Lung Altun, G.; Bilgi, S.; Altun, A. (Edirne)

55 Postural Orthostatic Tachycardia Warrants Investigation of Chiari I Malformation as a Possible Cause Pasupuleti, D.V.; Vedre, A. (Flint, Mich.)

No. 2

General Cardiology

57 LMNA Mutations in Cardiac Transplant Recipients Pethig, K. (Hannover); Genschel, J. (Berlin); Peters, T.; Wilhelmi, M.; Flemming, P. (Hannover); Lochs, H. (Berlin); Haverich, A. (Hannover); Schmidt, H.H.-J. (Berlin)

63 Relationship of Serum Cardiac Markers following Successful Percutaneous Coronary Intervention and Subsequent Exercise Capacity in Patients with Chronic Stable Angina: A Pilot Study Williams, S.G.; Stables, R.H.; Wright, D.J.; Taylor, S. (Liverpool); Thompson, D.; Tan, L.-B. (Leeds)

68 Left Ventricular Hypertrabeculation/Noncompaction and Stroke or Embolism Stöllberger, C.; Finsterer, J. (Wien)

73 Normalization of Negative T Waves in the Chronic Stage of Q Wave Anterior Myocardial Infarction as a Predictor of Myocardial Viability

Altun, A.; Durmus-Altun, G.; Birsin, A.; Gultekin, A.; Tatli, E.; Ozbay, G. (Edirne)

84 Stability of the ECG Features of Complete Right Bundle Branch Block over Time: A Methodological Study for Implementation in Research and Clinical Practice Madias, J.E.; Ashtiani, R.; Agarwal, H.; Narayan, V.K.; Win, M.; Sinha, A. (New York, N.Y./Elmhurst, N.Y.)

107 Aortic Stiffness Is an Independent Predictor of Left Ventricular Function in Patients with Coronary Heart Disease Sakuragi, S.; Iwasaki, J.; Tokunaga, N.; Hiramatsu, S. (Tottori); Ohe, T. (Okayama)
KARGER

(C) 2005 S. Karger AG, Basel

Fax +41613061234 E-Mail karger@karger.ch www.karger.com
Access to full text and tables of contents, including tentative ones for forthcoming issues: www.karger.com/crd issues 
Case Report

81 Cardiac Involvement in Facioscapulohumeral Muscular Dystrophy

Finsterer, J.; Stöllberger, C. (Vienna); Meng, G. (Würzburg)

Basic Science

92 Effects of Nimesulide, a Selective Cyclooxygenase-2 Inhibitor on Cardiovascular Alterations in Endotoxemia

Azab, A.N.; Kobal, S.; Rubin, M.; Kaplanski, J. (Beer-Sheva)

Arrhythmia and Electrophysiology

101 Electrocardiographic Abnormalities as Predictors for

Over-Range Lithium Levels

Hsu, C.-H.; Liu, P.-Y.; Chen, J.-H.; Yeh, T.-L.; Tsai, H.-Y.; Lin, L.-J. (Tainan)

Letters to the Editor

79 Is There a Seasonal Variation in Hospital Admissions for Acute-Onset Atrial Fibrillation?

Kountouris, E.; Korantzopoulos, P.; Dimitroula, V.; Bartzokas, A.; Siogas, K. (Ioannina)

89 Traumatic Right Ventricular Rupture: Antemortem Diagnosis Utilizing Transesophageal Echocardiography

Dharmashankar, K.C.; Dhawan, S.; Khurana, A.; Douglas-Jones, J.W.E. Tak, T. (Marshfield, Wisc.)

No. 3

Review

137 Mitochondrial Dysfunction as an Initiating Event in Atherogenesis: A Plausible Hypothesis

Puddu, P.; Puddu, G.M.; Galletti, L.; Cravero, E.; Muscari, A. (Bologna)

General Cardiology

113 Safety of Cardiac Rehabilitation in a Medically Supervised, Community-Based Program

Scheinowitz, M.; Harpaz, D. (Tel-Aviv)

143 Variation in Outcomes after Percutaneous Coronary Intervention in the United States and Predictors of Periprocedural Mortality

Mukherjee, D.; Wainess, R.M.; Dimick, J.B.; Cowan, J.A.; Rajagopalan, S Chetcuti, S.; Grossman, P.M.; Upchurch, G.R. (Ann Arbor, Mich.)

156 Association of Right Ventricular Dilatation with Bilateral Pulmonary Embolism, Pulmonary Embolism in a Main Pulmonary Artery and Lobar, Segmental and Subsegmental Pulmonary Embolism in 190 Patients with Acute Pulmonary Embolism

Sukhija, R.; Aronow, W.S.; Yalamanchili, K.; Lee, J.; McClung, J.A.; Levy, J.A.; Belkin, R.N. (Valhalla, N.Y.)

158 Association of Ankle-Brachial Index with Severity of Angiographic Coronary Artery Disease in Patients with Peripheral Arterial Disease and Coronary Artery Disease Sukhija, R.; Aronow, W.S.; Yalamanchili, K.; Peterson, S.J.; Frishman, W.H.; Babu, S. (Valhalla, N.Y.)

161 Heart Failure in Diabetes mellitus: Clinical Features and Prognostic Implications

Gorelik, O.; Almoznino-Sarafian, D.; Alon, I.; Shteinshnaider, M.; Chachashvily, S.; Tzur, I.; Modai, D.; Cohen, N. (Zerifin)

Cardiac Catheterization and Interventional Cardiology

123 Self-Expanding Coronary Stent (Radius) Implantation with Cutting Balloon Angioplasty

Lee, S.H.; Choi, S.-H.; Ko, Y.-G.; Choi, D.; Jang, Y.; Shim, W.-H. (Seoul)
Clinical Pharmacology

148 A Comparison of the Two $\beta$-Blockers Carvedilol and Atenolo on Left Ventricular Ejection Fraction and Clinical Endpoints after Myocardial Infarction. A Single-Centre, Randomized Study of 232 Patients

Jonsson, G.; Abdelnoor, M.; Müller, C.; Kjeldsen, S.E.; Os, I.; Westheim, A. (Oslo)

Epidemiology

131 Metabolic Syndrome in a Screened Worksite Sample: Prevalence and Predictors

Godefroi, R.; Klementowicz, P.; Pepler, C. (Nashua, N.H.); Lewis, B.; McDonough, K. (Wilmington, Del.); Goldberg, R.J. (Worcester, Mass.)

Letters to the Editor

118 Electrocardiographic Features of Hypothermia

Mustafa, S. (London); Shaikh, N. (Darby, Pa.); Gowda, R.M. (Brooklyn, N.Y.); Khan, I.A. (Baltimore, Md.)

120 Serum B-Type Natriuretic Peptide in STEMI Patients Treated with PCl

Grabowski, M.; Filipiak, K.J.; Karpinski, G.; Opolski, G. (Warsaw)

121 Detection of Chlamydia pneumoniae DNA in the Coronary Arteries and Bypass in Three Patients with Diffuse Coronary Artery Disease

Zorc, M.; Vraspir-Porenta, O.; Keše, D.; Petrovič, D.; Legan, M. (Ljubljana)

128 ST-Segment Elevation Pattern and Myocardial Injury Induced by Acute Pancreatitis

Korantzopoulos, P.; Pappa, E.; Dimitroula, V.; Kountouris, E.; Karanikis, P.; Patsouras, D.; Siogas, K. (Ioannina)

142 Shunt Obstruction after an Air Travel in an Adult Patient with Cyanotic Congenital Heart Disease Suda, K.; Matsumura, M.; Matsumoto, M. (Tenri City)

167 Noncompaction in Myotonic Dystrophy Type 1 on Cardiac MRI Finsterer, J.; Stöllberger, C.; Kopsa, W. (Vienna)

No. 4

Coronary Care

169 Body Temperature - A Marker of Infarct Size in the Era of Early Reperfusion

Ben-Dor, I.; Haim, M.; Rechavia, E.; Murininkas, D.; Nahon, M.; Harell, D.; Porter, A.; Iakobishvili, Z.; Scapa, E.; Battler, A.; Hasdai, D. (Tel Aviv)

Pediatric Cardiology

174 Study of Cardiac Rate and Rhythm Patterns in Ambulatory and Hospitalized Children

Massin, M.M.; Bourguignont, A.; Gérard, P. (Liège)

Cardiovascular Epidemiology and Prevention

180 Levels of, and Factors Associated with, C-Reactive Protein in Employees Attending a Company-Sponsored Cardiac Screening Program

Godefroi, R.; Klementowicz, P.; Pepler, C. (Nashua, N.H.); Lewis, B.; McDonough, K. (Wilmington, Del.); Goldberg, R.J. (Worcester, Mass.)

General Cardiology

185 Lack of Association between Common Polymorphisms in Genes of the Renin-Angiotensin System and Mortality afte Myocardial Infarction

Andrikopoulos, G.K.; Tzeis, S.M.; Needham, E.W.; Richter, D.J. (Athens); Zairis, M.N. (Piraeus); Gialafos, E.J.; Kardaras, F.G. (Athens); Foussas, S.G. (Piraeus); Stefanadis, C.I.; Toutouzas, P.K. (Athens); Mattu, R.; (Warwick) 
189 Isolated Type 2 Diabetes mellitus Causes Myocardial Dysfunction That Becomes Worse in the Presence of Cardiovascular Diseases: Results of the Myocardial Doppler in Diabetes Study 1 (MYDID)

Govind, S. (Bangalore); Brodin, L.-Å; Nowak, J.; Quintana, M.; Raumina, S. (Stockholm); Ramesh, S.S.; Keshava, R. (Bangalore); Saha, S. (Stockholm)

201 Predictors of Benefit in Angina Patients One Year after Completing Enhanced External Counterpulsation: Initia Responders to Treatment versus Nonresponders Lawson, W.E.; Hui, J.C.K. (New York, N.Y.); Kennard, E.D. (Pittsburgh, Pa.); Barsness, G. (Rochester, Minn.); Kelsey, S.F., (Pittsburgh, Pa.)

207 The Relation between Homocysteine and Calcific Aortic Valve Stenosis

Gunduz, H.; Arinc, H.; Tamer, A. (Bolu); Akdemir, R.; Ozhan, H. (Düzce); Binak, E. (İstanbul); Uyan, C. (Bolu)

Cardiac Catheterization and Interventional Cardiology

212 Short Stent Implantation for Routine Use Is Feasible in a High Proportion of Coronary Interventions and Yields a Low Restenosis Rate

Dietz, U.; Holz, N.; Dauer, C. (Wiesbaden); Meinert, R. (Mainz);

Lambertz, H. (Wiesbaden)
Letters to the Editor

196 Intracoronary Epinephrine for Contrast-Medium-Induced Microvascular Obstruction in a Chronically Hemodialyzed Patient

Lucreziotti, S.; Sponzilli, C.; Castini, D.; Di Domenico, E.; Fiorentini, C. (Milan)

199 High-Density Lipoprotein and Vascular Tone in Healthy Subjects

Koch, H.J. (Regensburg)

219 Author Index Vol. 103, 2005

220 Subject Index Vol. 103, 2005
S. Karger

Medical and Scientific Publishers

Basel $\bullet$ Freiburg $\bullet$ Paris $\bullet$ London

New York $•$ Bangalore $•$ Bangkok

Singapore $\cdot$ Tokyo $\bullet$ Sydney
Drug Dosage

The authors and the publisher have exerted every effort to ensure that drug selection and dosage set forth in this text are in accord with current recommendations and practice at the time of publication. However, in view of ongoing research, changes in government regulations, and the constant flow of information relating to drug therapy and drug reactions, the reader is urged to check the package insert for each drug for any change in indications and dosage and for added warnings and precautions. This is particularly important when the recommended agent is a new and/or infrequently employed drug.
All rights reserved.

No part of this publication may be translated into other languages, reproduced or utilized in any form or by any means, electronic or mechanical, including photocopying, recording, microcopying, or by any information storage and retrieval system, without permission in writing from the publisher or, in the case of photocopying, direct payment of a specified fee to the Copyright Clearance Center (see 'General Information').

(c) Copyright 2005 by S. Karger AG,

P.O. Box, CH-4009 Basel (Switzerland)

Printed in Switzerland on acid-free paper by

Reinhardt Druck, Base 